\title{
MICROSTRUCTURE AND TENSILE PROPERTIES OF FRICTION-STIR-PROCESSED Al-Li-Cu-Zr-Sc ALLOY
}

\author{
MIKROSTRUKTURA IN NATEZNE LASTNOSTI ZLITINE \\ Al-Li-Cu-Zr-Sc, IZDELANE S TORNO-VRTILNIM POSTOPKOM
}

\author{
Leipeng Song1,2, Yang Zhang ${ }^{1 *}$, Jian Wang1, Yalin Lu ${ }^{1}$ \\ ${ }^{1}$ School of Materials Engineering, Jiangsu University of Technology, Changzhou 213001, China \\ ${ }^{2}$ College of Aerospace Engineering, Nanjing University of Aeronautics and Astronautics, Zhongwu road 1801, Nanjing 210000, China
}

Prejem rokopisa - received: 2019-07-18; sprejem za objavo - accepted for publication: 2020-04-28

doi:10.17222/mit.2019.163

\begin{abstract}
Microstructure evolution and its influence on the tensile properties of a high-strength cast $\mathrm{Al}-3 \mathrm{Li}-1.5 \mathrm{Cu}-0.15 \mathrm{Zr}-0.15 \mathrm{Sc}$ alloy during friction-stir processing (FSP) are investigated in this paper. It is found that the coarsening of $\alpha$-Al dendrites in an as-cast alloy is insignificant after a solid-solution treatment. Most of the $\mathrm{Al}_{2} \mathrm{Cu}$ and $\mathrm{Al}_{6} \mathrm{CuLi}_{3}$ phases are dissolved into the matrix while the $\mathrm{Al}_{3}(\mathrm{Li}, \mathrm{Sc}, \mathrm{Zr})$ phase remains intact. During FSP, a complete dynamic recrystallization takes place in the stir zone and fine equiaxed grains are obtained. Residual intermetallic particles are also broken into fine particles and distributed uniformly in the matrix. The microstructure distribution in the stir zone is inhomogeneous and a strong $\{111\}$ texture and a weak $\{110\}$ texture are formed. After FSP, the tensile strength is significantly improved owing to the interaction of the grain refinement, breaking up of intermetallic phases and formation of texture.

Keywords: friction-stir processing, Al-Li alloy, microstructure, texture, mechanical properties
\end{abstract}

Avtorji v članku predstavljajo razvoj mikrostrukture in njen vpliv na mehanske lastnosti, določene z nateznim preizkusom, lite visokotrdnostne zlitine Al-3Li-1,5Cu-0,15Zr-0,15Sc, izdelane s torno-vrtilnim postopkom mešanja taline (FSP; angl.: friction stir processing). Ugotovili so, da so grobi $\alpha$-Al dendriti v liti zlitini nepomembni po njeni toplotni obdelavi z raztopnim žarenjem. Večina faz $\mathrm{Al}_{2} \mathrm{Cu}$ in $\mathrm{Al}_{6} \mathrm{CuLi}_{3}$ se raztopi v matrici, medtem ko faza $\mathrm{Al}_{3}(\mathrm{Li}, \mathrm{Sc}, \mathrm{Zr})$ ostane po raztopnem žarjenju. Avtorji ugotavljajo, da se med FSP izvede kompletna dinamična rekristalizacija v coni mešanja in nastanejo enakoosna zrna. Po raztopnem žarjenju se preostali intermetalni vključki prav tako lomijo med FSP v finejše delce in se enakomerno razporedijo po kovinski osnovi. Mikrostrukturna porazdelitev v coni mešanja je nehomogena ter ima močno $\{111\}$ in šibko $\{110\}$ teksturo. Avtorji zaključujejo, da se je po FSP natezna trdnost zlitine močno izboljšala zaradi udrobljenja mikrostrukture oz. zmanjšanja velikosti kristalnih zrn in delcev intermetalne faze ter nastanka teksture.

Ključne besede: torno-vrtilni postopek, zlitina Al-Li, mikrostruktura, tekstura, mehanske lastnosti

\section{INTRODUCTION}

Aluminum alloys with excellent strength and good anti-fatigue performance have a wide utilization in the aeronautic, astronautic and automobile industries. ${ }^{1}$ Low-density Al-Li alloys have attracted wide attention in the past decades as they help us reduce the weight of aero-structural components. ${ }^{2-4}$ By replacing traditional Al alloys with Al-Li alloys, the weight of the components can be decreased by 10-20\% and the stiffness improved by $15-20 \% .^{5}$

Friction-stir processing (FSP) is known as an important severe-plastic-deformation (SPD) technique, effective for achieving the microstructure refinement of $\mathrm{Al}$ alloys. ${ }^{6}$ Shukla et al. found that ultra-fine-grained (UFG) microstructures with a grain size of less than $1 \mu \mathrm{m}$ were achieved in Al-5024 alloys using FSP. ${ }^{7}$ The UFG structure was also obtained in an FSPed Al-Mg-SiC nanocomposite, which was attributed to a complete dynamic recrystallization (DRX) induced by $\mathrm{FSP}^{8} \mathrm{~A}$ recent research conducted by Zhao et al. pointed out that the

*Corresponding author's e-mail:

zhangyang@jsut.edu.cn (Yang Zhang) microstructure of the $6063 \mathrm{Al}$ alloy was obviously refined from $134 \mu \mathrm{m}$ to $5.2 \mu \mathrm{m}$ via FSP. ${ }^{9}$ It is noteworthy that most of the researches focused on the FSW of third-generation wrought Al-Li alloys, for instance, AA 2099, AA 2195 and AA 2198 alloys. ${ }^{10-12}$ Due to the high plastic-deformation capacity of FSP, FSP can also induce a significant grain refinement in cast Al-Li alloys. However, there is still little research work done on the FSP of as-cast Al-Li alloys.

Recently, several new Al-Li-Cu-Zr alloys containing a relatively high amount of Li have been developed and these alloys have been proved to have high strength. It was demonstrated that an $\mathrm{Al}-3 \mathrm{Li}-1 \mathrm{Cu}-0.1 \mathrm{Zr}-0.1 \mathrm{Er}$ alloy achieved an improvement in comprehensive mechanical properties owing to the $\mathrm{Al}_{3}(\mathrm{Er}, \mathrm{Zr}, \mathrm{Li})$ particles. ${ }^{13} \mathrm{~A}$ low-density and high-strength $\mathrm{Al}-3 \mathrm{Li}-1.5 \mathrm{Cu}-0.2 \mathrm{Zr}$ alloy was developed by A. T. Chen et al. ${ }^{14}$ Shi et al. reported that adding $\mathrm{Sc}(0.15 \%)$ into the cast $\mathrm{Al}-3 \mathrm{Li}-1.5 \mathrm{Cu}-$ $0.15 \mathrm{Zr}$ alloy could further improve the mechanical properties. ${ }^{15}$ However, FSPed Al-Li-Cu-Zr alloys have not yet been widely studied.

In the present work, a high-strength $\mathrm{Al}-3 \mathrm{Li}-1.5 \mathrm{Cu}-$ $0.15 \mathrm{Zr}-0.15 \mathrm{Sc}$ alloy was solid-solutioned and then sub- 
jected to FSP. The corresponding microstructural evolution and its influence on the mechanical properties of the FSPed alloy were studied.

\section{EXPERIMENTAL PART}

The Al-3Li-1.5Cu-0.15Zr-0.15Sc $(w / \%)$ alloy was fabricated from high-purity Al, Li (99.9 w/\%) and Al-50 $w / \% \mathrm{Cu}, \mathrm{Al}-10 w / \% \mathrm{Zr}, \mathrm{Al}-2$ w/\% Sc master alloys using a vacuum induction furnace with an argon atmosphere. The chemical composition of the as-cast ingot was determined with inductively coupled plasma-atomic emission spectroscopy and the real chemical composition was Al-2.96Li-1.57Cu-0.16Zr-0.13Sc $(w / \%)$. The cast shape was $250 \mathrm{~mm}$ long, $80 \mathrm{~mm}$ wide and $150 \mathrm{~mm}$ high. The as-cast alloy was solid-solutioned for $32 \mathrm{~h}$ at $500{ }^{\circ} \mathrm{C}$ followed by $24 \mathrm{~h}$ at $560{ }^{\circ} \mathrm{C}$, and then quenched in water. Before FSP, the solid-solutioned alloy was machined into plates that were $250 \mathrm{~mm}$ long, $150 \mathrm{~mm}$ wide and $8 \mathrm{~mm}$ thick, using wire-electrode cutting. FSP was carried out using an FSW machine (FSW-LW-BM16, FSW Technology Co., Ltd, Beijing, China) with a tool rotational speed of $1600 \mathrm{~min}^{-1}$ and feed speed of $60 \mathrm{~mm} / \mathrm{min}$. Figure 1 shows a photograph of the FSW machine applied in this study and a schematic of FSP where ND, PD and TD denote the normal direction, the processing direction and the transverse direction, respectively.

Microstructure observation was conducted on the as-cast, solid-solutioned and FSPed samples using light microscopy (LM, MR5000, Nanjing, China) and scanning electron microscopy (SEM, Simga 500VP, Zeiss, Oberochen, Germany) combined with energy-dispersive $\mathrm{X}$-ray spectroscopy (EDS, Inca, Oxford Instruments, Ox-
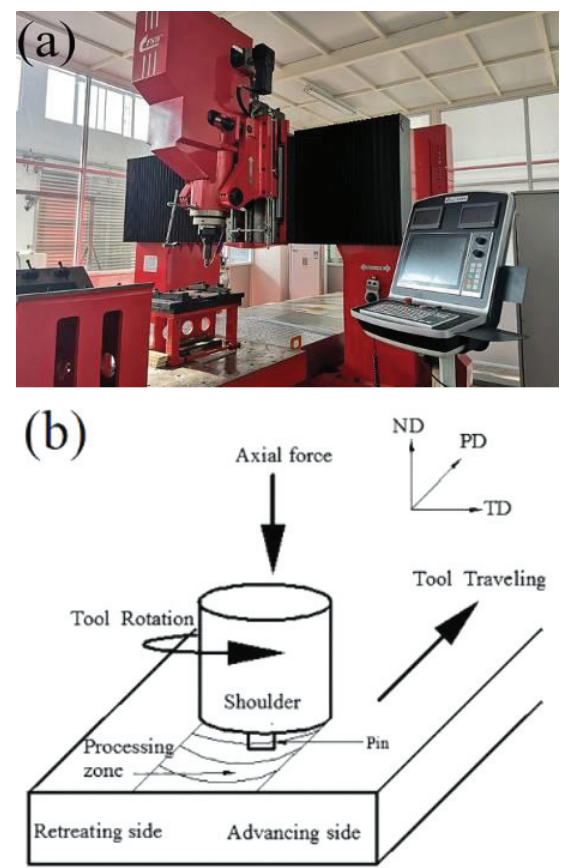

Figure 1: a) photograph of the FSW machine used in this study; b) schematic of FSP ford, UK). The texture characterization of the FSPed sample was examined with electron backscatter diffraction (EBSD, Inca, Oxford Instruments, Oxford, UK). Tensile specimens were cut using wire-electrode cutting along the processing direction. The tensile properties of the FSPed specimens were measured on a universal testing machine (CMT-5205, Wance, Shenzhen, China) at an initial strain rate of $1.67 \times 10^{-3} \mathrm{~s}^{-1}$ along the PD. These tests were carried out at least 3-5 times to obtain the mean values of tensile properties.

\section{RESULTS AND DISCUSSION}

Light microstructures and SEM images of the as-cast and solid-solutioned samples are included in Figure 2. As shown, the microstructure of the as-cast sample is composed of nearly equiaxed $\alpha$-Al dendrites and coarse intermetallic compounds scattered along the grain boundaries. The mean grain size of the as-cast sample is $\check{c} 30 \mu \mathrm{m}$. The intermetallic compounds in the as-cast sample mainly consist of $\mathrm{Al}_{2} \mathrm{Cu}, \mathrm{Al}_{6} \mathrm{CuLi}_{3}$ and $\mathrm{Al}_{3}(\mathrm{Li}, \mathrm{Sc}$, $\mathrm{Zr}){ }^{15}$ According to the SEM image from Figure 2c and the corresponding EDS results from Figure 2e to $2 \mathbf{f}$ ), the intermetallic compounds present at the grain boundaries are $\mathrm{Al}_{2} \mathrm{Cu}$ and $\mathrm{Al}_{6} \mathrm{CuLi}_{3}$ while the particle within the $\alpha$ - $\mathrm{Al}$ grains is the $\mathrm{Al}_{3}(\mathrm{Li}, \mathrm{Sc}, \mathrm{Zr})$ phase. Compared to the as-cast sample, the coarsening of the $\alpha$-Al grains during the solid-solution treatment is insignificant. The formation of the $\mathrm{Al}_{3}(\mathrm{Li}, \mathrm{Sc}, \mathrm{Zr})$ particles can suppress the growth of $\alpha$-Al grains. ${ }^{16,17}$ As shown in Figure 2d, most of the $\mathrm{Al}_{2} \mathrm{Cu}$ and $\mathrm{Al}_{6} \mathrm{CuLi}_{3}$ phases are dissolved into the matrix during solid solution, while the $\mathrm{Al}_{3}(\mathrm{Li}, \mathrm{Sc}, \mathrm{Zr})$ particles remain intact, indicating that the thermal stabil-
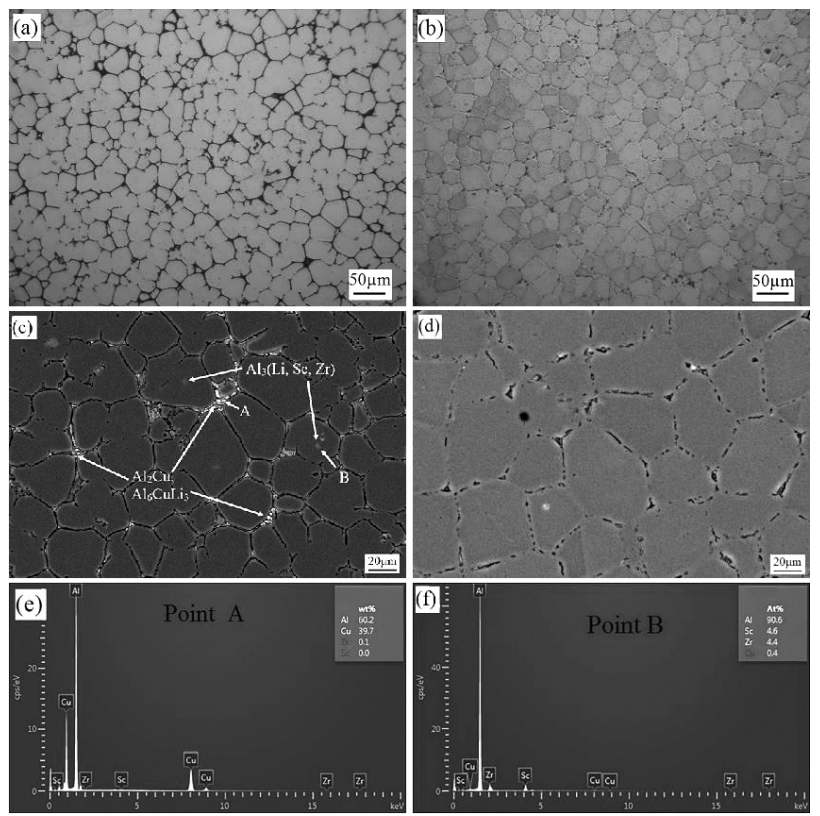

Figure 2: Microstructures of $(\mathrm{a}, \mathrm{c})$ the as-cast and $(\mathrm{b}, \mathrm{d})$ solidsolutioned samples and EDS results for points A and B from Figure $2 c$ 
ity of the $\mathrm{Al}_{3}(\mathrm{Li}, \mathrm{Sc}, \mathrm{Zr})$ phase is better than that of the $\mathrm{Al}_{2} \mathrm{Cu}$ and $\mathrm{Al}_{6} \mathrm{CuLi}_{3}$ phases. Since the dissolution of the $\mathrm{Al}_{2} \mathrm{Cu}$ and $\mathrm{Al}_{6} \mathrm{CuLi}_{3}$ phases is incomplete, some small particles are also observed at the grain boundaries.

The cross-sectional macrostructure of the FSPed sample is presented in Figure 3a. RS denotes the retreating side and AS denotes the advancing side. The typical zones in FSPed Al alloys, such as the stir zone (SZ), thermo-mechanically affected zone (TMAZ) and base metal $(\mathrm{BM})$ are marked. Figure $\mathbf{3 b}$ presents the light microstructure of Region 3 in the SZ, which is at the centre of the SZ of the FSPed sample. It is found that a complete DRX takes place in the SZ during the FSP and fine equiaxed grains are formed. A quantitative analysis of the average size is done in the following EBSD analysis. As shown in Figure 3c, besides the grain refinement induced by the DRX, the residual intermetallic compounds are also broken into fine particles and distributed uniformly in the matrix.

Figure 4 shows the inverse pole figures and pole figures of different regions in the SZ of the FSPed sample obtained with EBSD. The inverse pole figures in Figures 4a to $\mathbf{4 e}$ also confirm that the complete DRX takes place in the $\mathrm{SZ}$ and a fine equiaxed grain structure is formed. Compared to the BM, the average grain size in the $\mathrm{SZ}$ is refined to 3.7-4.8 $\mu \mathrm{m}$. The inverse pole figures also show that the average size and orientation of DRXed grains in different regions of the SZ of the FSPed sample are not the same. The largest average grain size is obtained in the centre of the SZ and the smallest average grain size is obtained at the bottom of the SZ. In addition, the pole figures illustrate the evolution of the texture in different regions. It is observed that the strong $\{111\}$ texture and weak $\{110\}$ texture are formed in the SZ. In addition, the intensity of the texture is higher at the RS than at the AS. As shown in Figure 4c, a simple shear texture is created
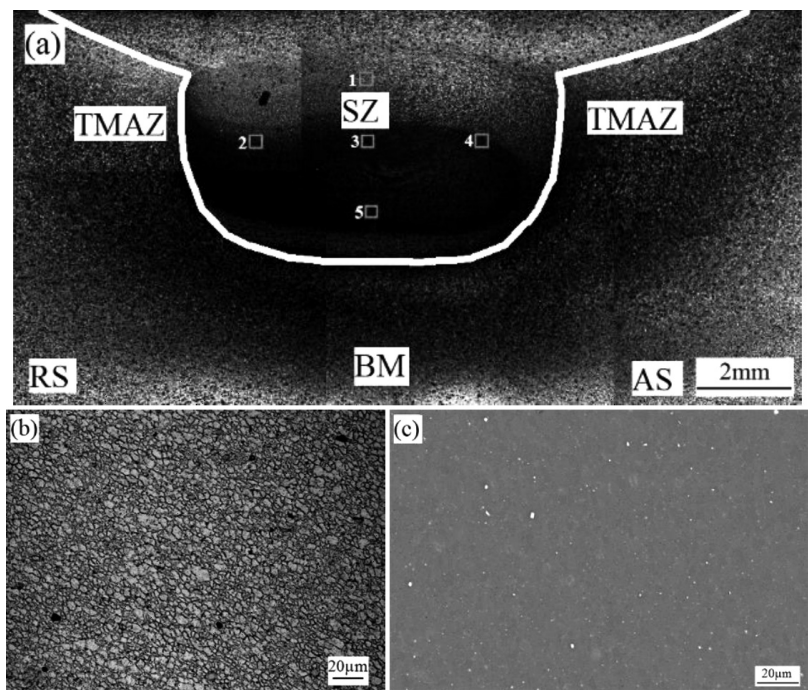

Figure 3: Cross-sectional macrostructure of the FSPed sample and microstructure of Region 3: a) cross-sectional macrostructure; b) light microstructure of Region 3; c) SEM image of Region 3 in the centre of the $\mathrm{SZ}$, namely $\mathrm{A} / \overline{\mathrm{A}}$ and $\mathrm{B} / \overline{\mathrm{B}}$ texture components. The emergence of the $\mathrm{B}$ texture component indicates that alargestrain is introduced into the SZ during the FSP. Texture components are primarily affected by the rotation of the stirring pin, due to which Regions 2 and 4 show the same texture components as Region 3, while the shear texture on the left and right is rotated around the ND. Moreover, Regions 1 and 5 also show similar shear components.

Table 1: Tensile properties of the studied alloy

\begin{tabular}{|l|c|c|c|c|}
\hline & $\begin{array}{c}\text { YS } \\
(\mathrm{MPa})\end{array}$ & $\begin{array}{c}\text { UTS } \\
(\mathrm{MPa})\end{array}$ & $\begin{array}{c}\text { EL } \\
(\%)\end{array}$ & \\
\hline Solid-solutioned & 104 & 290 & 25.8 & Ref. $^{15}$ \\
\hline T6 $\left(175^{\circ} \mathrm{C} \times 8 \mathrm{~h}\right)$ & 263 & 414 & 8.1 & Ref. $^{15}$ \\
\hline T6 $\left(175^{\circ} \mathrm{C} \times 32 \mathrm{~h}\right)$ & 291 & 415 & 5.5 & Ref. $^{15}$ \\
\hline FSPed & $334 \pm 2$ & $427 \pm 3$ & $5.6 \pm 1$ & $\begin{array}{c}\text { This } \\
\text { work }\end{array}$ \\
\hline
\end{tabular}

Table 1 gives the corresponding tensile properties of the FSPed sample. After the FSP, the yield strength (YS), ultimate tensile strength (UTS) and elongation to failure (EL) are $334 \mathrm{MPa}, 427 \mathrm{MPa}$ and $5.6 \%$, respectively. According to the ${ }^{15}$, the tensile properties of the solidsolutioned Al-3Li-1.5Cu-0.15Zr-0.15Sc alloy exhibit a relatively low strength and high elongation, with the YS, UTS and EL of $104 \mathrm{MPa}, 290 \mathrm{MPa}$ and $25.8 \%$. After the ageing at $175{ }^{\circ} \mathrm{C}$ for $8 \mathrm{~h}$, the YS, UTS and EL

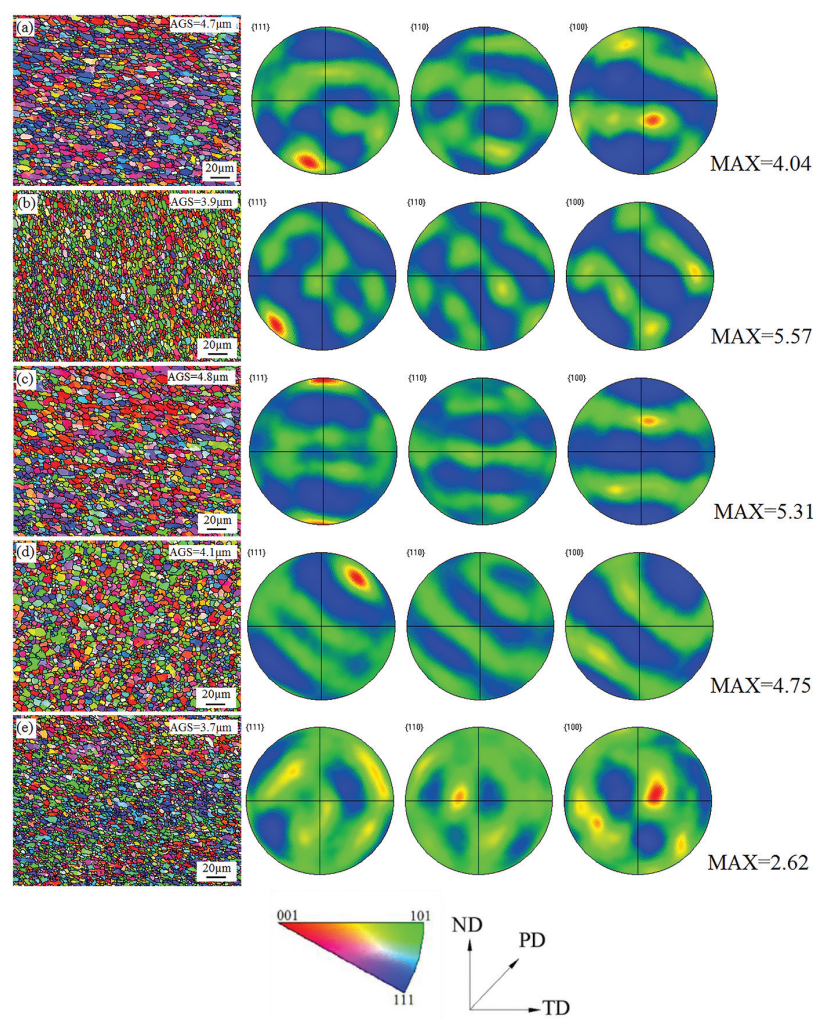

Figure 4: Inverse pole figures and pole figures of different regions in the SZ from Figure 3: a) Region 1; b) Region 2; c) Region 3; d) Region 4 and e) Region 5 
reached $263 \mathrm{MPa}, 414 \mathrm{MPa}$ and $8.1 \%$. Further ageing at $175{ }^{\circ} \mathrm{C}$ for $32 \mathrm{~h}$ resulted in a slight improvement in the YS but continuous deterioration in the EL, and the YS, UTS and EL were $291 \mathrm{MPa}, 415 \mathrm{MPa}$ and $5.5 \%$, respectively. The tensile test confirmed that the YS and UTS of the FSPed sample are higher than of the sample aged at $175{ }^{\circ} \mathrm{C}$ for $32 \mathrm{~h}$, showing that FSP is an effective means of improving the tensile properties of cast Al-Li alloys.

In this investigation, a complete DRX takes place in the SZ of the FSPed sample. However, further characterization reveals that the microstructure of the SZ is inhomogeneous. As shown in Figure 4, the coarsest DRXed grains are formed in the centre of the SZ, the DRXed grains in the upper region are coarser than those in the bottom region, and the DRXed grains in the right region are coarser than those in the left region. An inhomogeneous microstructure distribution in the SZ was also observed in FSPed Mg alloys. ${ }^{18}$ The DRX during FSP is due to the SPD and thermal exposure. The SPD is induced by the rotating pin while the thermal exposure is mainly generated by the friction between the shoulder and surface of the plates. Since the distribution of the deformation force and heat in the SZ is different during FSP, the resulting DRXed grains have different sizes in different regions.

Generally, the relationship between the grain size and YS follows the classic Hall-Petch equation. ${ }^{19}$ In this study, FSP leads to a fine microstructure in the Al-Li alloy. In the cast $\mathrm{Al}-3 \mathrm{Li}-1.5 \mathrm{Cu}-0.15 \mathrm{Zr}-0.15 \mathrm{Sc}$ alloy, the grain size is about $30 \mu \mathrm{m}$. Meanwhile, the grain size of the FSPed Al-3Li-1.5Cu-0.15Zr-0.15Sc alloy is sharply reduced to $3.7-4.8 \mu \mathrm{m}$. The tremendous improvement of the YS mainly benefits from the grain refinement. The grain refinement is accompanied by the increasing grain boundaries, which can hinder the movement of dislocation and enhance the strength. ${ }^{20}$ Moreover, as shown in Figure 3c, the residual intermetallic compounds are broken up into fine particles and distributed homogeneously in the matrix. The fine and homogenously distributed intermetallic compounds can also hinder the movement of dislocation via the Orowan strengthening mechanism. ${ }^{21,22}$ Besides the grain refinement and breaking up of intermetallic compounds, the formation of the texture also contributes to the improvement of the strength. As shown in Figure 4, the formation of the shear-texture component after FSP means that a massive stored strain occurs in the FSPed sample, indicating improved mechanical properties. ${ }^{23}$ Moreover, the low texture intensity is also propitious to ameliorate the tensile properties. ${ }^{24}$ However, it is found that, compared to the cast Al-3Li-1.5Cu-0.15Zr-0.15Sc alloy, the significant grain refinement in the FSPed Al-3Li-1.5Cu-0.15Zr-0.15Sc alloy shows little improving effect on the ductility. There may be two reasons for this. First, the residual particles can induce crack initiation during the tensile deformation and reduce the ductility. Second, the formation of the texture can make it difficult to slip, thus reducing the ductility.

\section{CONCLUSIONS}

An as-cast Al-3Li-1.5Cu-0.15Zr-0.15Sc alloy was solid-solutioned and subjected to FSP in this study. The evolution of the microstructure and its influence on the tensile properties of the FSPed sample were disclosed. Detailed findings can be summarized as follows:

1) During the solid-solution treatment, the coarsening of $\alpha$-Al grains in the as-cast sample is insignificant. Most of the $\mathrm{Al}_{2} \mathrm{Cu}$ and $\mathrm{Al}_{6} \mathrm{CuLi}_{3}$ phases are dissolved into the matrix while the $\mathrm{Al}_{3}(\mathrm{Li}, \mathrm{Sc}, \mathrm{Zr})$ phase remains intact.

2) During FSP, a complete DRX takes place in the SZ and fine equiaxed grains are obtained. The residual intermetallic compounds are also broken into fine particles and distributed uniformly in the matrix. The microstructure distribution in the SZ is inhomogeneous and a strong $\{111\}$ texture and weak $\{110\}$ texture are formed.

3) After FSP, the YS and UTS are significantly improved, confirming that FSP is an effective means of improving the tensile properties of cast Al-Li alloys. The enhancement of the strength results from the grain refinement, the breaking up of intermetallic compounds and the formation of texture.

\begin{tabular}{ll}
\multicolumn{2}{l}{ Abbreviations } \\
FSP & friction-stir processing \\
SPD & severe plastic deformation \\
UFG & ultra-fine grained \\
DRX & dynamic recrystallization \\
ND & normal direction \\
PD & processing direction \\
TD & transverse direction \\
LM & light microscopy \\
SEM & scanning electron microscopy \\
EDS & energy-dispersive X-ray spectroscopy \\
EBSD & electron backscatter diffraction \\
RS & retreating side \\
AS & advancing side \\
SZ & stir zone \\
TMAZ & thermo-mechanically affected zone \\
BM & base metal \\
YS & yield strength \\
UTS & ultimate tensile strength \\
EL & elongation to failure \\
&
\end{tabular}

\section{Acknowledgement}

This work was supported by the National Natural Science Foundation of China (No. 51601076), China Postdoctoral Science Foundation funded project (No. 2019M650096) and Postgraduate Research \& Practice Innovation Program of Jiangsu Province (SJCX18_1043). 


\section{REFERENCES}

${ }^{1}$ A. Malikov, I. Vitoshkin, A. Orishich, A. Filippov, E. Karpov, Microstructure and mechanical properties of laser welded joints of Al-Cu-Li and Ti-Al-V alloys, Journal of Manufacturing Processes, 53 (2020), 201-212, doi:10.1016/j.jmapro.2020.02.010

${ }^{2}$ R. J. Rioja, J. Liu, The evolution of Al-Li base products for aerospace and space applications, Metallurgical Materials Transaction A, 43 (2012), 3325-3337, doi:10.1007/s11661-012-1155-Z

${ }^{3}$ J. Zdunek, B. Adamczyk-Cieslak, M. Koralnik, M. Kulczyk, J. Mizera, The influence of combined hydrostatic extrusion and rolling on the microstructure, texture and mechanical properties of Al-Li alloys, Journal of Manufacturing Processes, 47 (2019), 254-262, doi:10.1016/j.jmapro.2019.09.042

${ }^{4} \mathrm{O}$. Gharbi, N. Birbilis, K. Ogle, Li reactivity the surface pretreatment of Al-Li alloy AA2050-T3, Electrochimica Acta, 243 (2017), 207-219, doi:10.1016/j.electacta.2017.05.038

${ }^{5}$ R. K. Gupta, N. Nayan, G. Nagasireesha, S. C. Sharma, Development and characterization of Al-Li alloys, Materials Science \& Engineering A, 420 (2006), 228-234, doi:10.1016/j.msea.2006.01.045

${ }^{6}$ E. Cetkin, Y. H. Celik, S. Temiz, Microstructure and mechanical properties of AA7075/AA5182 jointed by FSW, Journal of Materials Processing Technology, 268 (2019), 107-116, doi:10.1016/ j.jmatprotec.2019.01.005

${ }^{7}$ S. Shukla, M. Komarasamy, R. S. Mishra, Grain size dependence of fatigue properties of friction stir processed ultrafine-grained Al-5024 alloy, International Journal of Fatigue, 109 (2018), 1-9, doi:10.1016/j.ijfatigue.2017.12.007

${ }^{8}$ F. Khodabakhshi, A. P. Gerlich, P. Švec, Fabrication of a high strength ultra-fine grained $\mathrm{Al}-\mathrm{Mg}$-SiC nanocomposite by multi-step friction-stir processing, Materials Science \& Engineering A, 698 (2017), 313-325, doi:10.1016/j.msea.2017.05.065

${ }^{9}$ H. L. Zhao, Q. Pan, Q. D. Qin, Y. J. Wu, X. D. Su, Effect of the processing parameters of friction stir processing on the microstructure and mechanical properties of 6063 aluminum alloy, Materials Science \& Engineering A, 751 (2019), 70-79, doi:10.1016/j.msea. 2019.02.064

${ }^{10}$ Y. Lin, Z. Q. Zheng, Microstructural evolution of 2099 Al-Li alloy during friction stir welding process, Materials Characterization, 123 (2017), 307-314, doi:10.1016/j.matchar.2016.11.045

${ }^{11}$ J. T. Yoo, J. H. Yoon, K. J. Min, H. S. Lee, Effect of friction stir welding process parameters on mechanical properties and macro structure of Al-Li alloy, Procedia Manufacturing, 2 (2015), 325-330, doi:10.1016/j.pomfg.2015.07.057

${ }^{12}$ P. Cavaliere, A. De Santis, F. Panella, A. Squillace, Effect of anisotropy on fatigue properties of $2198 \mathrm{Al}-\mathrm{Li}$ plates joined by friction stir welding, Engineering Failure Analysis, 16 (2009) 6, 1856-1865, doi:10.1016/j.engfailanal.2008.09.024
${ }^{13}$ T. F. Yu, B. C. Li, A. Medjahed, L. G. Hou, R. Z. Wu, J. H. Zhang, Impeding effect of the $\mathrm{Al}_{3}(\mathrm{Er}, \mathrm{Zr}, \mathrm{Li})$ particles on planar slip and intergranular fracture mechanism of Al-3Li-1Cu-0.1Zr-X alloys, Materials Characterization, 147 (2019), 146-154, doi:10.1016/ j.matchar.2018.10.023

${ }^{14}$ A. T. Chen, Y. Peng, L. Zhang, G. H. Wu, Y. L. Li, Microstructural evolution and mechanical properties of cast Al-3Li-1.5Cu-0.2Zr alloy during heat treatment, Materials Characterization, 114 (2016), 234-242, doi:10.1016/j.matchar.2016.03.007

${ }^{15}$ C. C. Shi, L. Zhang, G. H. Wu, X. L. Zhang, A. T. Chen, J. S. Tao, Effect of Sc addition on the microstructure and mechanical properties of cast Al-3Li-1.5Cu-0.15Zr alloy, Materials Science \& Engineering A, 680 (2017), 232-238, doi:10.1016/j.msea.2016.10.063

${ }^{16}$ M. E. van Dalen, T. Gyger, D. C. Dunand, D. N. Seidman, Effects of $\mathrm{Yb}$ and $\mathrm{Zr}$ microalloying additions on the microstructure and mechanical properties of dilute Al-Sc alloys, Acta Materialia, 59 (2011), 7615-7626, doi:10.1016/j.actamat.2011.09.019

${ }^{17}$ C. B. Fuller, D. N. Seidman, Temporal evolution of the nanostructure of $\mathrm{Al}(\mathrm{Sc}, \mathrm{Zr})$ alloys: Part II-coarsening of $\mathrm{Al}(\mathrm{ScZr})$ precipitates, Acta Materialia, 53 (2005), 5415-5428, doi:10.1016/j.actamat.2005. 08.015

${ }^{18}$ S. Mironov, T. Onuma, Y. S. Sato, H. Kokawa, Microstructure evolution during friction-stir welding of AZ31 magnesium alloy, Acta Materialia, 100 (2015), 301-312, doi:10.1016/j.actamat.2015.08.066

${ }^{19}$ N. Hansen, Hall-Petch relation and boundary strengthening, Scripta Materialia, 51 (2004), 801-806, doi:10.1016/j.scriptamat.2004. 06.002

${ }^{20}$ F. Chen, Z. N. Chen, F. Mao, T. M. Wang, Z. Q. Cao, TiB 2 reinforced aluminum based in situ composites fabricated by stir casting, Materials Science \& Engineering A, 625 (2015), 357-368, doi:10.1016/ j.msea.2014.12.033

${ }^{21}$ S. Queyreau, G. Monnet, B. Devincre, Orowan strengthening and forest hardening superposition examined by dislocation dynamics simulations, Acta Materialia, 58 (2010), 5586-5595, doi:10.1016/ j.actamat.2010.06.028

${ }^{22}$ M. Balackrishnan, I. Dinaharan, R. Palanivel, R. Sathiskumar, Influence of friction stir processing on microstructure and tensile behavior of $\mathrm{AA} 6061 / \mathrm{Al}_{3} \mathrm{Zr}$ cast aluminum matrix composites, Journal of Manufacturing Processes, 38 (2019), 148-157, doi:10.1016/j.mapro. 2018.12.039

${ }^{23}$ M. Sarkari Khorrami, N. Saito, Y. Miyashita, M. Kondo, Texture variations and mechanical properties of aluminum during severe plastic deformation and friction stir processing with $\mathrm{SiC}$ nanoparticles, Materials Science \& Engineering A, 744 (2019), 349-364, doi:10.1016/j.msea.2018.12.031

${ }^{24}$ H. Y. Chen, L. Fu, P. Liang, Microstructure, texture and mechanical properties of friction stir welded butt joints of 2A97 Al-Li alloy ultra-thin sheets, Journal of Alloys and Compounds, 692 (2017), 155-169, doi:10.1016/j.jallcom.2016.08.330 